\title{
The adductor pectoral fin muscle of Micropogonias furnieri (Perciformes: Sciaenidae): a morphological and histochemical study
}

\author{
María Sol Hernández ${ }^{1}$, María Victoria Longo $^{1^{*}},{\text { Clelia Viviana Devincenti }{ }^{1} \& \text { Alcira Ofelia Díaz }}^{1}$
}

\author{
${ }^{1}$ Instituto de Investigaciones Marinas y Costeras (IIMyC), Departamento de Biología, FCEyN, CONICET, Universidad \\ Nacional de Mar del Plata. Funes 3250, $3^{\circ}$ piso, (7600) Mar del Plata, Argentina. \\ *Corresponding author. E-mail: mvlongo@mdp.edu.ar
}

\begin{abstract}
The adductor pectoral fin muscle in post-spawning females of the white croaker Micropogonias furnieri (Desmarest, 1823 ) is described from a morphological, histochemical and morphometric perspectives. A description of the morphological characteristics was conducted after dissections in different layers, down to the deep layer. Five muscles were found: superficial, medial, radial and deep adductors, and dorsal arrector. Their fibers were studied after applying histochemical techniques: succinic dehydrogenase (SDH) to reveal mitochondria, periodic acid-Schiff (PAS) for glycogen, Sudan black for lipids, myosin adenosinetriphosphatase (mATPase) to reveal the types of fibers, and modified mATPase to evidence the capillaries. Fiber diameters were measured and the number of capillaries was counted. Fiber subtypes named small, medium and large were found within red, pink and white fibers, the latter prevailing. Staining homogeneity was observed in white fibers after alkaline pre-incubations. The number of capillaries decreased from red to white fibers. Due to the prevalence of white fibers, the adductor muscle of the pectoral fins appears to be capable of rapid and discontinuous movements, which are important to body stabilization during subcarangiform swimming. The homogenous staining of white fibers observed in this research corresponds to the post-spawning gonad stage studied.
\end{abstract}

KEY WORDS. fin musculature, histochemistry, morphology, morphometry, white croaker.

The myotomal and pectoral fin musculature of teleost fish has three different types of muscle fibers: red, white and pink. Differences in the histochemical, biochemical and ultrastructural features of fiber types have been found between species (Devincenti et al. 2000a, b, 2009).

Enzyme histochemistry provides useful information for the classification of the different fiber types of vertebrates and invertebrates (Ogata 1988, Alvarez et al. 2012). Specifically, there are tests that measure the activity of the enzyme myosin adenosinetriphosphatase (mATPase) and the oxidative capacity of fibers. Slow and rapid contraction fibers can be differentiated with the mATPase technique. Rapidly contracting fibers stain more intensely than slowly contracting fibers. In turn, pre incubations at different pH's as well as changes in the incubation temperature, allow the detection of a great variety of muscular fiber types. The speed of contraction and the oxidative capacity of fibers tend to vary inversely (JoHnston 1981, Biewener 2003).

Environmental factors have a variable impact on the skeletal musculature of fish. For instance, hyperplasic annual growth phases have been observed in the white musculature of mugilids (CARPené \& Veggetti 1981). Furthermore, seasonal his- tochemical and immunochemical variations have been observed in the muscle fibers of the pectoral fins of flatfish (CHAYEN et al. 1993). Beside environmental (extrinsic) factors, intrinsic factors such as gonad stage also influence the properties of muscular fibers. For instance, modifications of the ratio myosin/actin and changes in the biochemical and physicochemical features of actomyosin were observed in the myotomal muscle of hakes (CRUPKIN et al. 1988, Roura et al. 1990). Additionally, a variation of the histochemical activity of the mATPase of myotomal white fibers, which correlate with the gonad stage, has been observed in scienid species (DEvincentr et al. 2000a).

The pectoral fins, which some fish species use for their primary propulsion, are modified in some other species for different functions (Walker \& Westneat 2002). The swimming modes of fish species can be varied, but there are two main modes: labriform and subcarangiform. In the first, the fins are used for locomotion, while the miotomal musculature gives rigidity to the body. In the second, the pectoral fins are used to stabilize and to maneuver the body, while undulations from the back of the body generate the movement (JOHNSTON 1989, WARDLE et al. 1995, Fernández \& CaLvo 2009). Diverse studies have been 
conducted on the pectoral muscles of Antarctic labriform fishes (Johnston 1989, Fernández \& Calvo 2009) and on subcarangiform fishes (Chayen et al. 1987, 1993, Patterson et al. 2008, Devincenti et al. 2009, 2015).

The pectoral fins of teleost fishes are formed by abductor or extensor muscles, and adductor or flexor muscles. The number of pectoral muscles varies greatly among species. In highly derived fish species, the pectoral fins are located closer to the dorsum than to the venter and are actively used for swimming (Cousseau 2010).

The Whitemouth Croaker, Micropogonias furnieri (Desmarest, 1823), is a teleost fish that inhabits marine, brackish and fresh water environments. It has a wide distribution, from the Yucatán Peninsula (Mexico) to $41^{\circ} \mathrm{S}$ (Argentina), and a subcarangiform type of swimming (Cousseau \& Perrotta 2013). Adults usually develop in the shallow waters of the continental platform, on muddy and sandy substrates (BERMARDEs et al. 2005). The Whitemouth Croaker is one of the most important demersal fishes of the South American estuaries, and is widely used for commercial and recreational purposes in Brazil, Argentina and Uruguay (ManickCHAND-HeILEMAN \& KenNy 1990, MaCCHI et al. 2011, VieIRA et al. 1998, СHAO 2002). In terms of biomass, it is the dominant species of the Río de la Plata's estuary (JAUREGUIZAR et al. 2003).

After conducting preliminary morphological and histochemical studies on the pectoral fin muscles of M. furnieri, we encountered three fiber types at the muscle insertion zone of the fin: superficial red, deep white and intermediate pink (Devincentr et al. 2009). No studies have yet analyzed in a more detailed way the morphology and composition of the fiber types of the adductor pectoral fin muscle of this Sciaenidae species. With this in mind, we provide a morphological, histochemical and morphometric characterization of the adductor pectoral fin muscle of post-spawning females of $M$. furnieri. Our goal was to relate the characteristics of the muscle fibers with the way of swimming and the gonad stages of the species.

\section{MATERIAL AND METHODS}

Females of M. furnieri ( $\mathrm{n}=10$, length $38.25 \pm 4.65 \mathrm{~cm}$, weight $629 \pm 219.77 \mathrm{~g}$ ), obtained from sport and commercial fishing at the municipality of Mar del Plata (Argentina), were used in this study. The animals were sacrificed by cervical dislocation, following the guidelines of the American Fisheries Society (AFS 2004). The pectoral fins and gonads of every individual were removed. The gonads were processed for their inclusion in paraffin, and the scale proposed by Brown-Petersen et al. (2011) was used to determine the gonad stage. Only the post-spawning stage was observed. The pectoral fins were used both for the morphological description of the muscle and the histochemical techniques.

Fresh samples, and specimens fixed in formaldehyde buffer were dissected from the superficial to the deep plane of the muscle. Photographs of the different muscle layers were taken with an Olympus SP-350 digital camera. The morphology, origin and insertion of every muscle were macroscopically observed, and the orientation and fiber types were determined (Cousseau 2010).

The adductor pectoral fin muscle was removed and fixed in liquid nitrogen. Approximately $15 \mu \mathrm{m}$-thick seriated cryostat cuts were made on the entire muscular mass; the muscles were not separated because they are very fragile, and excessive manipulation makes them unsuitable for the rapid freezing fixation required to perform the histochemical techniques. The hematoxylin-eosin technique (H-E) was used to verify the transversal orientation of the fibers, and the histochemical techniques were performed as follows:

1. Succinic dehydrogenase (SDH) (Defendi \& Pearson 1955, DevinCENTI et al. 2015): to evidence the oxidative capacity of the fiber. The activity of this enzyme was demonstrated using the nitroblue tetrazolium technique. In the control, sodium succinate was replaced by sodium malonate.

2. Periodic acid Schiff (PAS) (HотсHкISs 1948): to evidence glycogen. Samples were treated with periodic acid and colored with Schiff's reagent. Controls were made with $\alpha$-amylase prior to the treatment with periodic acid.

3. Sudan Black (CHAyen et al. 1973): to evidence neutral lipids. Sections were stained in a saturated solution of color in $70 \%$ ethyl alcohol. In the controls the sections were treated with acetone half an hour before staining.

4. Myosin adenosinetriphosphatase (mATPase): to identify different fiber types based on the contraction speed. The GUTH \& Samaha (1970) method adapted for fish (Johnston \& Tota 1974) was used. The modifications proposed by DevinCENTI (1998) and Longo \& Díaz (2013) were implemented: sections were pre-incubated in buffered glycine $/ \mathrm{NaOH}$ at $\mathrm{pH}$ 's 9.8, 10.4 and 10.6, and with acetate buffer at pH's 4.6 and 4.3. Controls were prepared by replacing ATP with sodium glycerophosphate.

5. Modified mATPase to evidence capillaries and fiber diversity, applying the original RosenblatT et al. (1987) technique with the following modifications: the material was fixed in 5\% formaldehyde, sucrose $0.36 \mathrm{M}$ and $\mathrm{Cl}_{2} \mathrm{Ca} 0.068 \mathrm{M}$ at ambient temperature and at $4^{\circ} \mathrm{C}$ from one to five minutes; incubation at ambient temperature.

In order to determine mean fiber diameter, 100 red, pink and white fibers per animal $(n=5)$ were measured with the technique developed by te KronNIE et al. (1983). From the mean diameter, the fiber area was obtained with the following formula (Alnaqeeb \& Goldspink 1986): $\mathrm{A}=(\mathrm{D} / 2)^{2} \mathrm{x}(\varpi)$, where $\mathrm{A}=$ area of a fiber type, and $\mathrm{D}=$ mean diameter of a fiber type.

To determine the number of capillaries vascularizing the red, pink and white muscle fibers, 100 fibers of each type were analyzed in five specimens. For each fiber type, the percentage of fibers surrounded by $0,1,2,3,4$ and 5 capillaries was calculated. The average number of peripheral capillaries (PC) per fiber type was also obtained. With the PC and the area of each fiber 
type, the fiber area per peripheral capillary (APC) was calculated (Mosse 1978): $\mathrm{APC}=\mathrm{A} / \mathrm{PC}$.

Statistical analysis was performed with the SigmaPlot 12.0 program. Mean diameters and the number of capillaries between different fibers types were compared using the Kruskal-Wallis (ZAR 2010) test. The frequency histograms for the mean diameter of every fiber were obtained with the Minitab 16 program.

\section{RESULTS}

\section{Morphology}

The adductor pectoral fin muscle in post-spawning females of $M$. furnieri is composed of five different muscles, distributed in two layers: a more superficial layer, attached to the skin, and a deeper layer, attached to the skeletal elements.

The superficial musculature consists of: the superficial adductor, the medial adductor and the radial adductor. The superficial adductor, with pink and white fibers, elongated and rectangular in shape, originates in the cleithrum and the scapula, and is inserted on the medium surface of the fin rays by tendons (Fig. 1). The medial adductor, triangular in shape and composed of white fibers, comes from the cleithrum and is inserted on the medium rays of the fin, through tendons (Figs. $1,2)$. The slender and elongated radial adductor is composed of white fibers, and connects the radials and the coracoid with the ventral rays of the fin (Figs. 1, 2).

In the deep plane, below the superficial adductor, the triangle-shaped dorsal arrector, composed of pink and white fibers, was found. Its origin comes from the cleithrum, coracoid and scapula, and it is inserted on the upper rays of the fin by tendons (Figs. 2, 3). Ventral to the radial adductor, the rounded deep adductor, comprising red, pink and white fibers, is found; its origin comes from the coracoid and the cleithrum. It inserts through tendons on the base of the inferior rays of the fin (Figs. 2, 3).

\section{Histochemistry}

Red, pink and white fibers were found in the adductor muscle. Three fiber subtypes were categorized: small, medium and large fibers, each with their own histochemical properties.

The PAS and SDH techniques resulted in a strong reaction from the small red fibers, while medium and large fibers displayed a moderate reaction (Figs. 4,5 ). The mATPase activity of the three red fiber types was strong and stable at $\mathrm{pH} 9.8$, and light at pHs 10.4 (Fig. 8) and 10.6. As for the acid pre-incubation, red fiber activity was strong and stable, and the fibers deactivated only after long pre-incubation periods (Table 1).

Small and medium pink fibers reacted moderately to SDH and PAS, while large fibers reacted only slightly (Figs. 4, 5 ). The mATPase activity on small and medium pink fibers was moderate at $\mathrm{pH}$ 9.8, losing its activity at pH's 10.4 (Figs. 8, 9) and 10.6. On the other hand, the mATPase activity of large pink fibers was stable and strong after alkaline pre-incubation and for long periods (Table 1). The activity after acid pre-incubation was moderate to strong for all three fiber subtypes at different pH's (Fig. 10) and pre-incubation times (Table 1).

Table 1. Histochemistry of the adductor pectoral fin muscle of Micropogonias furnieri.

\begin{tabular}{|c|c|c|c|c|c|c|c|c|c|}
\hline & \multicolumn{3}{|c|}{ Red Fibers } & \multicolumn{3}{|c|}{ Pink Fibers } & \multicolumn{3}{|c|}{ White Fibers } \\
\hline & s & $\mathrm{m}$ & I & $s$ & $\mathrm{~m}$ & 1 & s & $\mathrm{m}$ & 1 \\
\hline \multirow[t]{2}{*}{ SDH } & $3 / 4$ & 2 & $1 / 2$ & 2 & 2 & 1 & p 1 & 1 & 0 \\
\hline & & & & & & & $\mathrm{d} 0 / 1$ & 0 & 0 \\
\hline \multirow[t]{2}{*}{ PAS } & 4 & $3 / 4$ & $2 / 3$ & $2 / 3$ & 2 & $1 / 2$ & $\mathrm{p} \mathrm{0/1}$ & 1 & 0 \\
\hline & & & & & & & d 0 & 0 & 0 \\
\hline mATPase & 4 & 4 & $3 / 4$ & $2 / 3$ & 3 & 2 & p 2 & 2 & 3 \\
\hline$S / P$ & & & & & & & d 2 & 2 & 2 \\
\hline mATPase & $1 / 4$ & $1 / 3$ & $2 / 3$ & $1 / 2$ & $1 / 2$ & 4 & $\mathrm{p} 1 / 2$ & 2 & $2 / 3$ \\
\hline 9.8 & & & & & & & d $1 / 2$ & $1 / 2$ & 2 \\
\hline mATPase & 1 & 1 & 1 & 1 & $1 / 2$ & $3 / 4$ & $\mathrm{p} 1 / 2$ & 2 & 2 \\
\hline 10.4 & & & & & & & d 1 & 2 & 2 \\
\hline mATPase & 1 & 1 & 1 & 1 & $1 / 2$ & $3 / 4$ & $\mathrm{p} 1 / 2$ & 2 & 2 \\
\hline 10.6 & & & & & & & d $1 / 2$ & 2 & 2 \\
\hline mATPase & $1 / 3$ & $1 / 2$ & $2 / 3$ & $2 / 3$ & $2 / 3$ & $2 / 3$ & $\mathrm{p} 1 / 2$ & $1 / 2$ & $1 / 2$ \\
\hline 4.6 & & & & & & & d $1 / 2$ & $1 / 2$ & $1 / 2$ \\
\hline mATPase & $0 / 1$ & 0 & 0 & 3 & $2 / 3$ & $2 / 3$ & p 3 & $2 / 3$ & 1 \\
\hline 4.3 & & & & & & & d 3 & 1 & 1 \\
\hline
\end{tabular}

Reactivities: negative (0); weak (1); moderate (2); strong (3); very strong (4). Distal (d) zone; large (l); medium (m); myosin-adenosintriphosphatase (mATPase); Periodic Acid-Shiff $(\mathrm{PAS})$; proximal $(\mathrm{p})$ zone; small $(\mathrm{s})$; succinate dehydrogenase (SDH).

Among the white fibers, two different histochemical zones were determined: a proximal zone, following the pink fibers in the insertion region of the muscle on the fin rays, and a distal one, in the region of the bone origin. The small and medium white fibers of the proximal zone slightly reacted to SDH and PAS, while the large failed to react to either technique (Figs. 6, $7)$. In the distal zone, white small fibers presented a very slight activity for SDH, and both medium and large fibers showed no reaction; the PAS-activity was negative for all three fiber types (Fig. 7). In relation to the mATPase, the activity of the three fiber types was moderate and stable in both zones after alkaline pre-incubations (Fig. 9). The activity of white fibers from the proximal zone at pH's 4.6 and 4.3 was variable, as the pre-incubation times increased, and a mosaic pattern was observed (Fig. 10). On the other hand, fibers at the distal zone, at $\mathrm{pH} 4.6$, had moderate activity during short pre-incubation periods; after longer periods the activity decreased (Table 1). At pH 4.3, after 5 min pre-incubation, the small white fibers had a strong reaction, and the medium and large fibers had a weak reaction (Fig. 11).

For the Sudan Black technique, red, pink and white fibers of both zones had no reaction.

The modified mATPase technique for capillaries (one-minute formaldehyde fixation) allowed evidencing both fibers and capillaries. Red fibers showed no activity, pink fibers gave moderate activity and white fibers revealed moderate to weak activity (Figs. 12-14). 

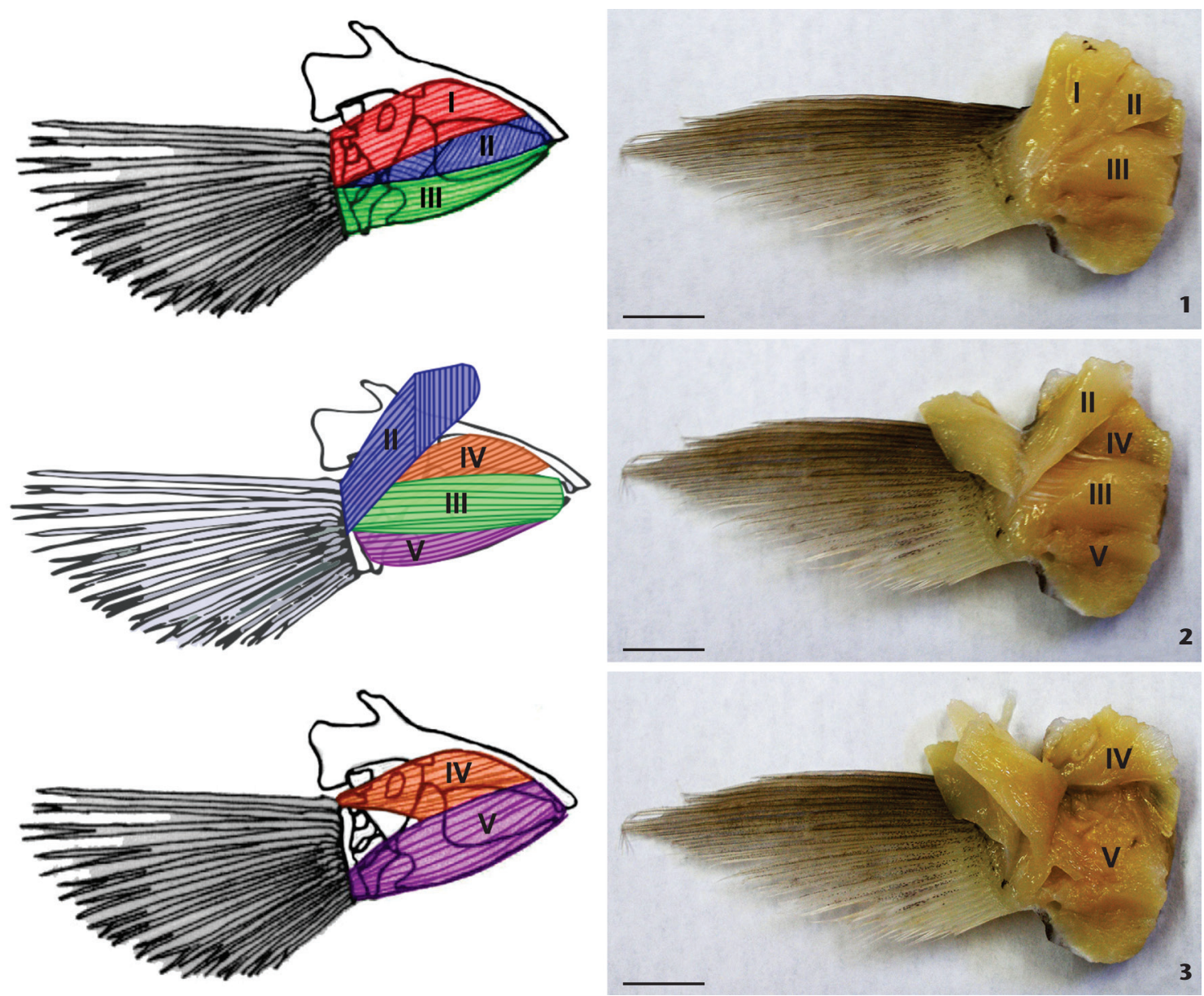

Figures 1-3. Diagram of the adductor pectoral fin muscles of Micropogonias furnieri. (1). Superficial view showing the adductor superficialis (I), adductor medialis (II) and adductor radialis (III), (bar = $1 \mathrm{~cm})$. (2). Superficial view showing adductor medialis (II), adductor radialis (III), adductor profundus (V) and arrector dorsalis (IV); no adductor superficialis is evidenced, $(\mathrm{bar}=1 \mathrm{~cm})$. (3). Superficial view showing adductor profundus (V) and arrector dorsalis (IV); no adductor medialis is evidenced, $(\mathrm{bar}=1 \mathrm{~cm})$.

\section{Morphometry}

Red fibers had an average mean of $39.33 \pm 14.31 \mu \mathrm{m}$ (range 16.2-75.51 $\mu \mathrm{m}$ ) and a round appearance. They were the least abundant of all fiber types, and were only present below the tissue and intermingled with some pink fibers.

Pink fibers, polyhedral in shape, presented an average diameter of $48.11 \pm 21.19 \mu \mathrm{m}$ (range 14.63-110.71 $\mu \mathrm{m}$ ) and were found among the red and white fibers.

White fibers prevailed over the other two types: the ones in the proximal zone, with a mean diameter of $73.68 \pm 28.44$ $\mu \mathrm{m}$ (range 21.5-152.16 $\mu \mathrm{m}$ ) and those in the distal zone, with a mean diameter of $77.34 \pm 31.32 \mu \mathrm{m}$ (range 27.61-162.16 $\mu \mathrm{m}$ ) and polyhedral in shape.

Significant differences in diameter were observed between: a) red and pink fibers $(\mathrm{p}<0.05)$ (Fig. 15); b) red and proximal zone white fibers $(\mathrm{p}<0.05)($ Fig. 16); $\mathrm{c})$ red and distal zone white fibers $(\mathrm{p}<0.05)$ (Fig. 17); d) pink and proximal zone white fibers $(\mathrm{p}<0.05)$ (Fig. 18) and e) pink and distal zone white fibers $(\mathrm{p}<$ 0.05 ) (Fig. 19). No significant differences were found between the white fibers of both zones ( $p<0.05)$ (Fig. 20).

The average number of capillaries surrounding red fibers was 1.51 and the percentage of fibers surrounded by no capillaries was $16 \%$. In the proximal zone, the average number of capillaries surrounding pink and white fibers was less than the average number of capillaries surrounding red fibers. The percentage of fibers not surrounded by capillaries was as follows: $44 \%$ for pink fibers, $33 \%$ for proximal zone white fibers and $52 \%$ for distal zone white fibers. White fibers of the distal zone had a maximum of three capillaries per fiber, while white fibers of the proximal zone had a maximum number of four (Table 2). The APC increased from red to white fibers in the proximal zone (Table 3). 

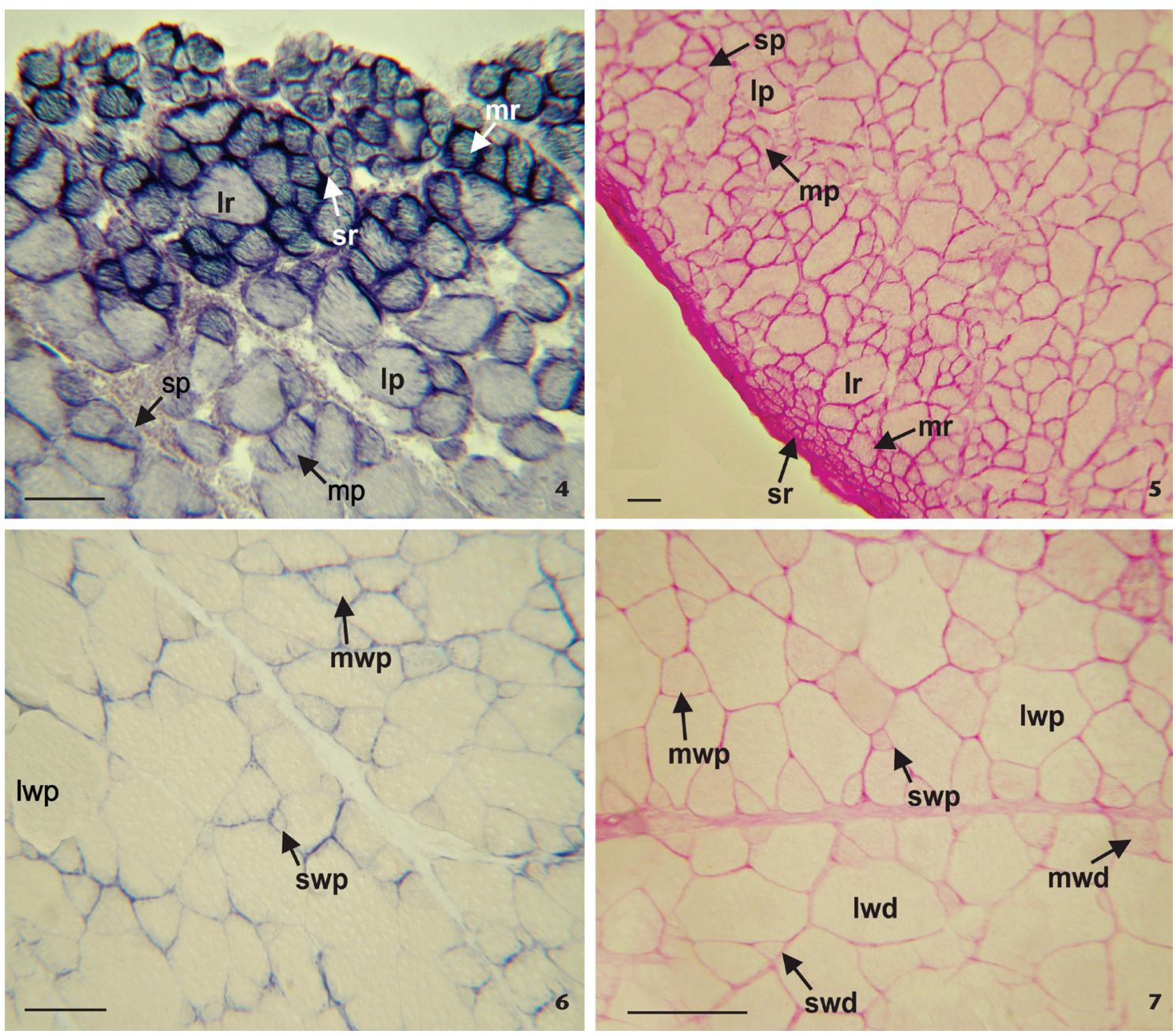

Figures 4-7. Histochemical staining of red, pink and white fibers from the adductor fin muscle of Micropogonias furnieri. (4). Red fibers showing strong staining (SDH technique); pink fibers showing weak reaction to SDH (lp: large pink, Ir: large red, mp: medium pink, mr: medium red, sp: small pink, sr: small red), (bar $=100 \mu \mathrm{m})$. (5). Periodic acid-Schiff (PAS) showing small red fibers (sr) with very strong stain intensity, and small pink (sp) fibers with moderate activity; medium and large fibers react weakly to PAS (Ip: large pink, Ir: large red, mp: medium pink, $\mathrm{mr}$ : medium red), (bar $=50 \mu \mathrm{m})$. (6). The small (swp) and medium (mwp) white fibers of the proximal zone show a weak reaction to $\mathrm{SDH}$; large fibers (Iwp) have no reaction, $(\mathrm{bar}=100 \mu \mathrm{m})$. (7). White fibers of the proximal zone react weakly to PAS; white fibers of the distal zone have no reaction (Iwd: large white distal, Iwp: large white proximal, mwd: medium white distal, mwp: medium white proximal, swd: small white distal, swp: small white proximal), (bar $=150 \mu \mathrm{m})$.

Table 2. Capillary supply of the adductor pectoral fin muscle of Micropogonias furnieri.

\begin{tabular}{|c|c|c|c|c|c|c|}
\hline \multirow[b]{2}{*}{ Fibre } & \multicolumn{5}{|c|}{ Percentage of fibers surrounded by $0-5$ capillaries } & \multirow{2}{*}{ PC } \\
\hline & 0 & 1 & 2 & 3 & 4 & \\
\hline Red & 16 & 37 & 28 & 18 & 1 & $1.51^{\mathrm{a}}$ \\
\hline Pink & 44 & 30 & 22 & 4 & & $0.86^{\mathrm{bc}}$ \\
\hline White proximal zone & 33 & 46 & 15 & 4 & 2 & $0.96^{\mathrm{b}}$ \\
\hline White distal zone & 52 & 37 & 10 & 1 & & $0.60^{c}$ \\
\hline
\end{tabular}

References: peripheral capillary average (PC). Similar superscripts express no statistically significant differences. Different superscripts indicate statistically significant differences $(\mathrm{p}<0.05)$.
Table 3. Standardized data of capillarization for the mean transverse area of each muscle fiber type in the adductor pectoral fin muscle of Micropogonias furnieri.

\begin{tabular}{lcccc}
\hline \multicolumn{1}{c}{ Fibre } & $\mathrm{D}(\mu \mathrm{m})$ & $\mathrm{A}\left(\mu \mathrm{m}^{2}\right)$ & $\mathrm{PC}$ & $\mathrm{APC}\left(\mu \mathrm{m}^{2}\right)$ \\
\hline Red & $39.33 \pm 14.310^{\mathrm{a}}$ & 1214.27 & 1.51 & 804.15 \\
Pink & $48.11 \pm 21.19^{\mathrm{b}}$ & 1816.94 & 0.86 & 2112.72 \\
White proximal zone & $73.68 \pm 28.44^{\mathrm{c}}$ & 4261.56 & 0.96 & 4439.12 \\
White distal zone & $77.34 \pm 31.26^{\mathrm{c}}$ & 4695.46 & 0.60 & 7825.76 \\
\hline
\end{tabular}

References: area per muscle fiber type (A); area per peripheral capillary (APC); mean diameter (D); peripheral capillary average (PC). Similar superscripts express no statistically significant differences. Different superscripts indicate statistically significant differences $(p<0.05)$. 

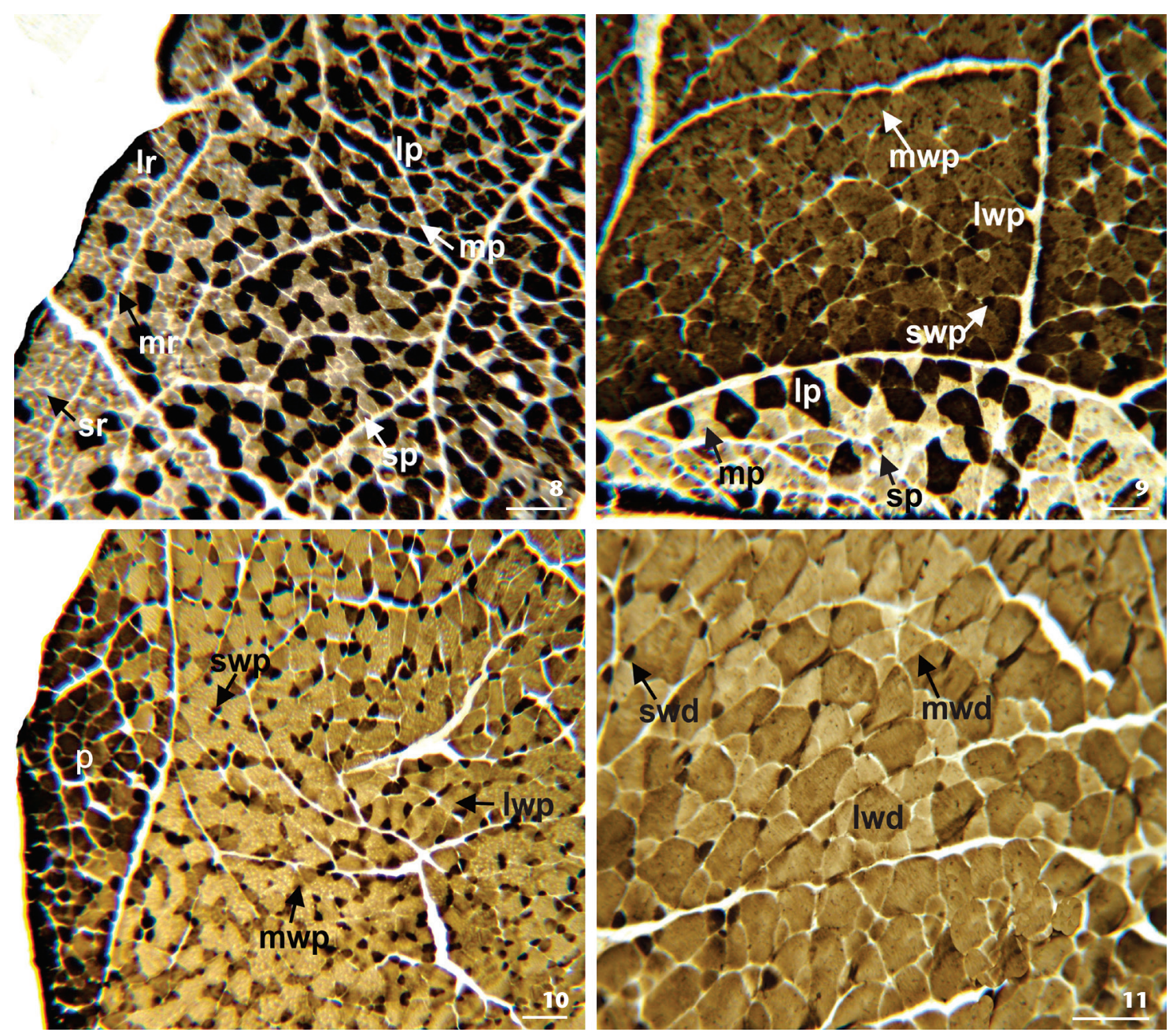

Figures 8-11. Histochemical staining of mATPase activity in the adductor fin muscle of Micropogonias furnieri. (8). mATPase activity with pre-incubation at $\mathrm{pH} 10.4$ showing red and pink fibers; small and medium fibers lose their activity; large fibers show a strong reaction (Ip: large pink, Ir: large red, mp: medium pink, mr: medium red, sp: small pink, sr: small red), (bar = $100 \mu m$ ). (9). mATPase activity with pre-incubation at $\mathrm{pH}$ 10.4. A homogeneous staining of white fibers of the proximal zone is shown (lp: large pink, Iwp: large white proximal, mp: medium pink, mwp: medium white proximal, sp: small pink, swp: small white proximal), $($ bar $=120 \mu \mathrm{m}) .(10)$. mATPase activity with pre-incubation at $\mathrm{pH} 4.3$; white fibers of the proximal zone showing a mosaic pattern of staining (Iwp: large white proximal, mwp: medium white proximal, p: pink, swp: small white proximal), (bar $=120 \mu \mathrm{m})$. (11). mATPase with pre-incubation at pH 4.3 showing white fibers of distal zone; small white fibers (swd) exhibit a strong reaction; medium ( $\mathrm{mwd}$ ) and large (Iwd) fibers show a moderate reaction, (bar $=80 \mu \mathrm{m})$.

\section{DISCUSSION}

The composition of the adductor pectoral fin muscle of M. furnieri, in our data, is consistent with the findings of other investigations on teleost fish in general (WinterbotTom 1974, Thorsen \& Westneat 2005, Cousseau 2010). However, the presence and morphology of these muscles vary among species (THORsen \& Hale 2005, Miano et al. 2013). For instance, according to Diogo $\&$ Abdala (2007) in Danio rerio (Hamilton, 1822) the superficial and deep adductor muscles are not individualized, but comprise a single entity. In M. furnieri, on the other hand, these muscles are separated by connective tissue into two fascicles, and are thus considered individual muscles.

The adductor muscle of the pectoral fins of $M$. furnieri is mainly composed of white fibers and, to a lesser extent, red and pink fibers, just as in the myotomal musculature and the abductor muscle of the species (Devincenti et al. 2000a, 2009). The anatomy of the abductor muscle of the stripped weakfish 

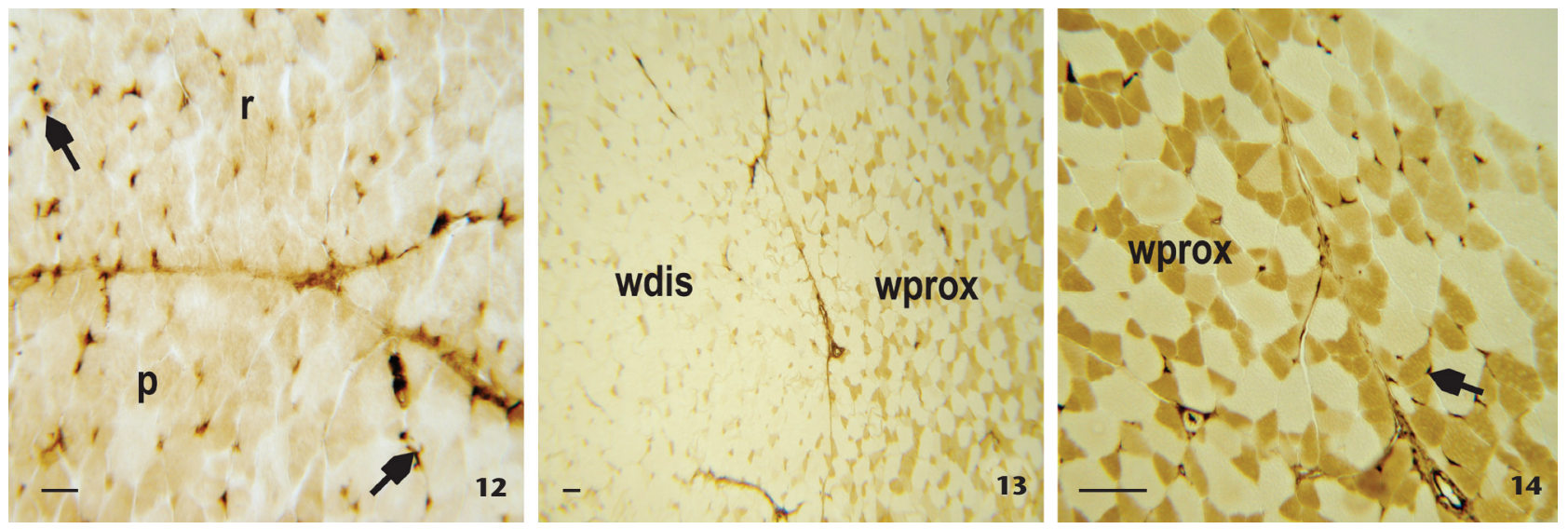

Figures 12-14. Histochemical staining of mATPase for capillaries from the adductor fin muscle of Micropogonias furnieri. (12). The number of capillaries (black arrow) in red fibers ( $r$ ) is greater than those found in the other fiber types; pink fibers ( $p$ ) have an intermediate irrigation, $($ bar $=150 \mu \mathrm{m})$. (13). The technique shows two different white fibers zones: proximal (wprox) and distal (wdis), (bar = 50 $\mu \mathrm{m}) .(14)$. The white fibers proximal (wprox) zone exhibits more irrigation than the distal zone (black arrow: capillaries), (bar = $130 \mu \mathrm{m})$.
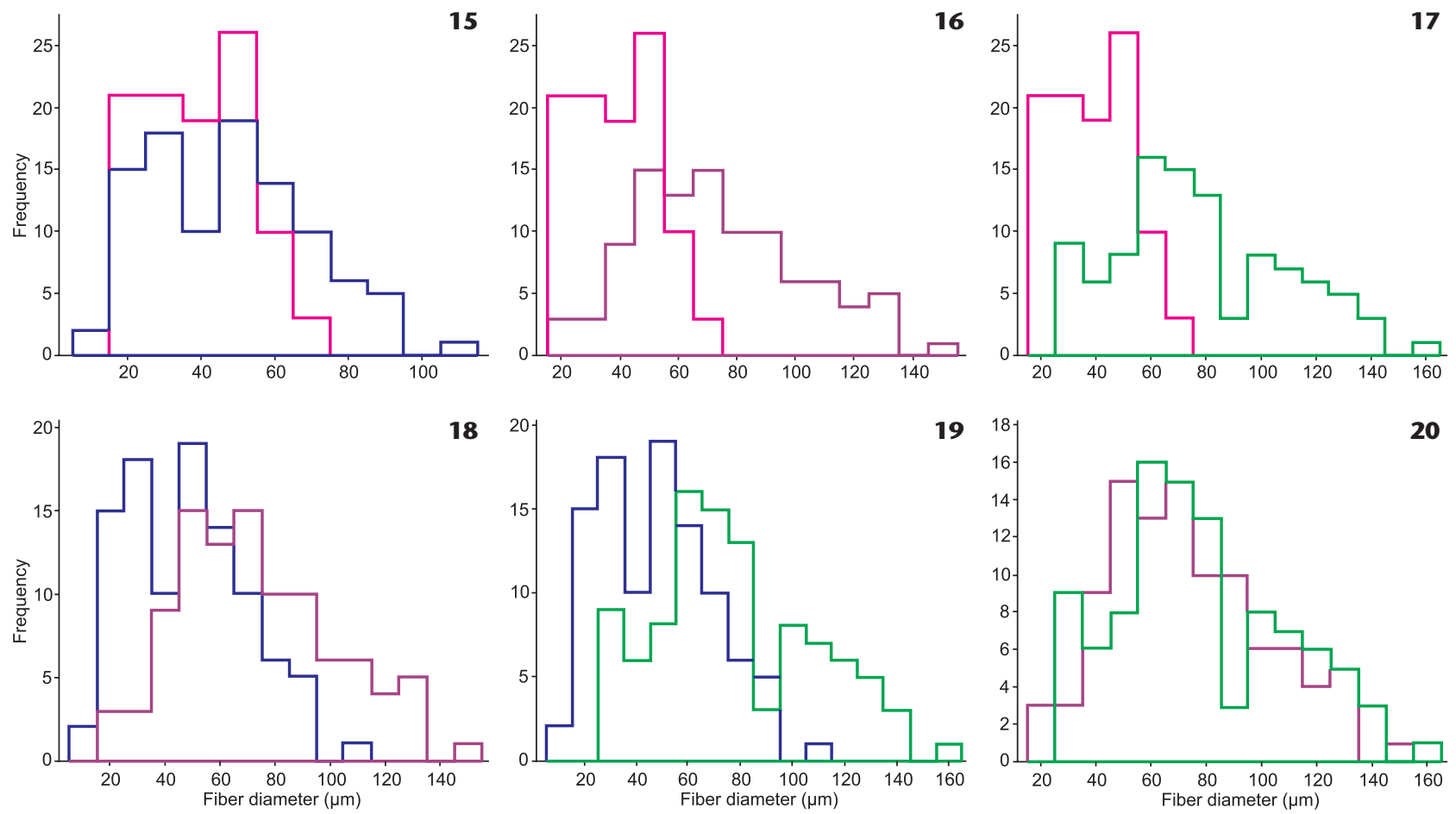

Figures 15-20. Frequency histogram of fiber diameters of the adductor fin muscle of Micropogonias furnieri. (15). Red and pink fibers. (16). Red and white fibers from the proximal zone. (17). Red fibers and white fibers from the distal zone. (18). Pink and white fibers from the proximal zone. (19). Pink and white fibers from the distal zone. (20). White fibers from the proximal and distal zones. Pink line, red fibers; blue line, pink fibers; purple line, proximal zone white fibers; green line, distal zone white fibers.

Cynoscion guatucupa (Cuvier, 1830) (Sciaenidae) (Devincenti et al. 2015), which also presents a subcarangiform mode of swimming, is also consistent with this model.
The arrangement of the small red fiber in the adductor muscle of the pectoral fin of $M$. furnieri is not consistent with the arrangement of the small red fiber in the corresponding 
myotomal muscle (DEvincentr et al. 2000a. In the fins, the red fibers are round, and are located below the connective tissue, while in the myotomal musculature they form spherical groups within the red musculature. This small red fiber subtype was also found in the abductor of M. furnieri and C. guatucupa (DEvINCENTI et al. 2009, 2015).

Medium red fibers had a mATPase activity that agrees with the description of Iвabe Martinez et al. (2000) of "typical red fibers" of species like Seriola dumerili (Risso, 1810), Diplodus vulgaris (Geoffroy Saint Hilaire, 1817), Trachinus draco Linnaeus, 1758 and Liza aurata (Risso, 1810). It also agrees with the description of DeVInCENTI (1998) of the myotomal musculature of M. furnieri.

The large red fibers of the adductor pectoral fin muscle of $M$. furnieri presented the same metabolic features described for the "other red" fiber type of the myotomal musculature of this species, and species such as Oreochromis niloticus (Linnaeus, 1758) and Thunnus orientalis (Temminck \& Schlegel, 1844) (DAL PAI-SILVA et al. 2003, Roy et al. 2012). On the other hand, the activity of the mATPase exhibited a pattern opposite to the one found in the myotomal and abductor muscles (DEvincentr et al. 2000a, 2009). Ibabe Martinez et al. 2000, described this type of fiber like "infiltrated pink fibers".

Pink fibers were consistent with those of the abductor muscle with regards to the mATPase activity after alkaline treatments, while activity in both muscles was different for acid treatments. Moreover, the oxidative activity and the glycogen content of pink fibers in the adductor muscle were higher than in the abductor muscle (DevincenTI et. al 2009). This is no surprise since the adductor muscle is involved in slower and continuous movement during fin upstrokes (THORSEN \& WESTNEAT 2005).

The distribution of the white fibers of the adductor pectoral fin muscle of $M$. furnieri was consistent with that found in the abductor muscle of C. guatucupa (DevincenTI et al. 2015): a proximal zone with a mosaic of white fibers, and a distal zone with more homogeneous staining fibers. However, while the mean diameters of white fibers in both zones had significant differences in $C$. guatucupa (Devincentr et al. 2015), they were similar in M. furnieri.

Differences have been found in the histochemical profile of the white fibers of the myotomal musculature of $M$. furnieri and C. guatucupa, according to the gonad stage. In females of M. furnieri, white muscles at post-spawning and/or resting stages presented great resistance to alkaline and acid treatments, with a homogeneous mATPase activity. However, in maturation and pre-spawning stages the white muscle was less resistant to those treatments, resulting in a mosaic of white fibers (DEVINCENTI et al. 2000a). In the white muscle of the pre-spawning hake a change in the ratio myosin/actin was found (CRUPKIN et al. 1988). The contractile properties of the white muscle of Myoxocephalus scorpius (Linnaeus, 1758) vary according to the reproductive cycle (JAMEs \& JOHNSTON 1998). According to our work, the staining homogeneity of white fibers to the mATPase technique at different pHs agree with the post-spawning gonad stage of the individuals under study.
The technique used to determine capillaries also allowed the identification of fiber types. Nevertheless, the fixation time influenced their expression: long fixation periods determined the total loss of fiber activity, and only the capillaries became evident. Short fixation periods allowed the observation of fibers and capillaries. With this same technique, red fibers gave low activity, and white and pink fibers gave from moderate to high. Opposite results were found in the myotomal muscle of M. furnieri, C. guatucupa and Engraulis anchoita Hubbs \& Marini, 1935 (Devincenti et al. 2000a, b, 2015). In mammals, prolonged fixation stained the capillaries and, in turn, the reaction was more intense in type II (rapid) fibers than in type I (slow) fibers (RosenblatT et al. 1987). In bird muscles, however, this technique permitted the detection of capillaries only (Fouces et al. 1993).

The distribution of capillaries in fibers of the adductor pectoral fin muscle of $M$. furnieri was coincident with that of the teleost fish musculature (Mosse 1978, Devincentr et al. 2000b). The two white muscle zones presented differences in relation to the number of capillaries supplying them, decreasing from the proximal to the distal region. A positive correlation exists between the blood supply and the oxidative capacity of fibers in every white muscle zone. Similar results were found (DEvincentr et al. 2015) for the abductor muscle of C. guatuсupa. The greater vascularization of the continually active red muscle offer the potential needed to guarantee an adequate transport of substances to and from the muscular fibers. On the contrary, the dependence of the white muscle on the anaerobic metabolism seems to be a consequence of low vascularization (Mosse 1978).

According to the results of this study, we highlight the dominance of white fibers in the pectoral fins of M. furnieri. This fact, undoubtedly, is correlated with the subcarangiform way of swimming, where the pectoral fin is involved in the execution of fast and discontinuous movements in order to stabilize and maneuver the body. Moreover, the homogenous staining of the white muscle would be related with the gonadal stage here studied.

\section{ACKNOWLEDGMENTS}

This research was supported by grants from the University of Mar del Plata, Argentina.

\section{LITERATURE CITED}

AFS (2004) Guidelines for the Use of Fishes in Research. Bethesda, American Fisheries Society, 1004p.

Alnaqeeb MA, Goldspink G (1986) Changes in fibre type, number and diameter in developing and ageing skeletal muscle. Journal of Anatomy 153: 31-45.

Alvarez GI, Díaz AO, Longo MV, Becerra F, Vasallo AI (2012) Histochemical and Morphometric Analyses of the Musculature of the Forelimb of the Subterranean Rodent Ctenomys talarum 
(Octodontoidea). Anatomia, Histologia, Embryologia 41: 317-325. doi: 10.1111/j.1439-0264.2012.01137.x

Bernardes RA, Figueiredo JL, Rodrigues AR, Fischer LG, Vooren CM, Haimovici M, Rossi-Wongtschowski CLDB (2005) Peixes de Zona Econômica Exclusiva da Região Sudeste-Sul do Brasil: Levantamento com armadilhas, pargueiras e redes de arrasto de fundo. São Paulo, Editora da Universidade de São Paulo, 295p.

Biewener AA (2003) Animal locomotion. New York, Oxford University Press, 281p.

Brown-Peterson NJ, Wyanski DM, Saborido-Rey F, Macewicz BJ, Lowerre-BARbieri SK (2011) A Standardized Terminology for Describing Reproductive Development in Fishes. Marine and Coastal Fisheries: Dynamics, Management and Ecosystem Science 3: 52-70. doi: 10.1080/19425120.2011.555724

Carpenè E, Veggetti A (1981) Increase in muscle fibres in the lateralis muscle (white portion) of Mugilidae (Pisces, Teleostei). Experentia 37: 191-193. doi: 10.1007/BF01963227

Chao LN (2002) Sciaenidae. In: CARPENTER KE (Ed.). The living marine resources of the western central Atlantic. Norfolk, FAO Species Identification Guide for Fishery Purposes, American Society of Ichthyologists and Herpetologists Special Publication 5, vol. 3.

Chayen J, Bitensky L, Butcher RG (1973) Practical Hitochemistry. London, John Wiley \& Sons, 286p.

Chayen NE, Freundlich A, Squire JM (1987) Comparative histochemistry of a flatfish fin muscle and of other vertebrate muscles used for ultrastructural studies. Journal of Muscle Research and Cell Motility 8: 358-371. doi: 10.1007/ BF01568892

Chayen NE, Rowlerson A, Squire JM (1993) Fish muscle structure: Fibre types in flatfish and mullet fin muscles using histochemistry and antimyosin antibody labelling. Journal of Muscle Research and Cell Motility 14: 533-542. doi: 10.1007/BF00297216

Cousseau MB (2010) Los peces óseos (Clase Actinopterygii y Sarcopterygii), p. 237-461. In: Cousseau MB, Díaz de Astarloa JM, Ehrlich MD, Fabré NN, Figueroa DE (Eds.) Ictiología: Aspectos fundamentales - la vida de los peces sudamericanos. Mar del Plata, Eudem, 670p.

Cousseau MB (2010) Ictiología: Aspectos fundamentales; La vida de los peces sudamericanos. Mar del Plata, EUDEM, p. 274-275.

Cousseau MB, Perrotta RG (2013) Peces marinos de Argentina: Biología, distribución, pesca. Mar del Plata, INIDEP, 167p.

Crupkin MC, Montecchia LC, Trucco RE (1988) Seasonal variations in gonadosomatic index, liver-somatic index and myosin/ actin ratio in actomyosin of mature hake (Merluccius hubbsi). Comparative Biochemistry and Physiology, Part A: Physiology, 89: 7-10. doi: 10.1016/0300-9629(88)91131-0

Dal Pai-Silva M, Carvalho RF, Pellizon CH, Dal Pai V (2003) Muscle fibre types in tilapia do Nilo (Oreochromis niloticus) from larval to adult: histochemical, ultrastructural and morphometric study. Tissue and Cell 35: 179-187. doi: 10.1016/S00408166(03)00019-3

Defendi V, Pearson B (1955) Quantitative estimation of succinic dehydrogenase activity in a single microscopic tissue section. Journal of Histochemistry and Cytochemistry 3: 61-69. doi: 10.1177/3.1.61

Devincenti CV, Díaz AO, Goldemberg AL (2000a) Lateral musculature in the whitemouth croaker (Micropogonias furnieri): its characterization with respect to different gonadal conditions. Anatomia, Histologia, Embryologia 29: 65-72. doi: 10.1046/j.1439-0264.2000.00225.x

Devincenti CV, Díaz AO, Goldemberg AL (2000b) Characterization of the Swimming Muscle of the Anchovy Engraulis anchoita (Hubbs \& Martini 1935). Anatomía, Histología Embryología 29: 197-202. doi: 10.1046/j.1439-0264.2000.00251.x

Devincenti CV, Díaz AO, Goldemberg AL (2009) Pectoral fins of Micropogonias furnieri: a histochemical and ultrastructural study. Fish Physiology and Biochemistry 35: 317-23. doi: 10.1007/s10695-008-9216-3

Devincenti CV, Longo MV, González Castro M, Díaz AO (2015) Morphological and histochemical characterization of the pectoral fin muscle of the stripped weakfish, Cynoscion guatucupa. Acta Zoologica 96: 199-208. doi: 10.1111/azo.12067

Diogo R, Abdala V (2007) Comparative Anatomy, Homologies and Evolution of the Pectoral Muscles of Bony Fish and Tetrapods: A New Insight. Journal of Morphology 268: 504-517. doi: 10.1002/jmor.10531

Fernández DA, Calvo J (2009) Fish muscle: The exceptional case of notothenioids. Fish Physiology and Biochemistry 35: 43-52. doi: 10.1007/s10695-008-9282-6

Fouces V, Torrella JR, Palomeque J, Viscor G (1993) A histochemical ATPase method for the demonstration of the muscle capillary network. Journal of Histochemistry and Cytochemistry 41: 283-289. doi: 10.1177/41.2.7678272

Guth L, SAmaha FJ (1970) Procedure for the histochemical demonstration of actomyosin ATPase. Experimental Neurology 28: 365-367. doi: 10.1016/0014-4886(70)90244-X

HoтchкIss RD (1948) A micro chemical reaction resulting in the staining of polysaccharide structures in fixed tissue preparations. Archives of Biochemistry 16: 131-141.

Ibabe Martínez I, Gil Cano F, Ramirez Zarzosa G, Vázquez JM, Latorre R, López Albors O, Arencibia A, Orenes YM (2000) Histochemical and morphometric aspects of the lateral musculature of different species of teleost marine fish of the Percomorphi order. Anatomia, Histologia, Embryologia 29: 2011-2219. doi: 10.1046/j.1439-0264.2000.00255.x

JAMEs R, JOHNSTON IA (1998) Scaling of muscle performance during escape responses in the fish Myoxocephalus scorpius L. Journal of Experimental Biology 201: 913-923.

Jaureguizar AJ, Menni R, Bremec C, Mianzan H, Lasta C (2003) Fish assemblage and environmental patterns in the Río de la Plata estuary. Estuarine Coastal Shelf Science 56: 921-933. doi: 10.1016/S0272-7714(02)00288-3 
JoHnston IA (1981) Quantitative analysis of muscle breakdown during starvation in the marine flat fish Pleuronectes platessa. Cell and Tissue Research 214: 369-386. doi: 10.1007/ BF00249218

Johnston IA (1989) Antarctic fish muscles-structure, function and physiology. Antarctic Science 1: 97-108. doi: 10.1017/ S0954102089000167.

Johnston IA, TотA B (1974) Myofibrillar ATPase in the various red and white trunk muscles of the tunny (Thunnus thynnus L.) and the tub gurnard (Trigla lucerna L.). Comparative Biochemistry and Physiology Part B: Comparative Biochemistry 49: 367-373. doi: 10.1016/0305-0491(74)90172-2

Longo MV, Díaz AO (2013) The claw closer muscle of two estuarine crab species, Cyrtograpsus angulatus and Neohelice granulata (Grapsoidea, Varunidae): histochemical fibre type composition. Acta Zoologica 94: 233-239. doi: 10.1111/j.1463-6395.2011.00548.x

Macchi GJ, Acha ME, Lasta CA (2011) Desove y fecundidad de la corvina rubia Micropogonias furnieri Desmarest, 1823 del estuario del Río de la Plata, Argentina. Boletín Instituto Español de Oceanografía 12: 99-113.

ManickChand-Heileman SC, KenNy JS (1990) Reproduction, age, and growth of the whitemouth croaker Micropogonias furnieri (Desmarest 1823) in Trinidad waters. Fishery Bulletin 88: 523-529.

Miano JP, Loesser-Casey KE, Fine ML (2013) Description and Scaling of Pectoral Muscles in Ictalurid Catfishes. Journal of Morphology 274: 467-477. doi: 10.1002/jmor.20108

Mosse PR (1978) The distribution of capillaries in the somatic musculature of the two vertebrate types with particular reference to teleost fish. Cell Tissue Research 187: 281-303. doi: 10.1007/BF00224371

Ogata T (1988) Morphological and cytochemical features of fiber types in vertebrate skeletal muscle. Anatomy and Cell Biology 3: 229-275.

Patterson SE, Mook LB, Devoto SH (2008) Growth in the larval zebrafish pectoral fin and trunk musculature. Developmental Dynamics 237: 307-315. doi: 10.1002/dvdy.21400

Rosenblatt JD, Kuzon WM, Plyley J, Pynn B, Mckee N (1987) A histochemical method for the simultaneous demonstration of capillaries and fiber type in skeletal muscle. Stain Technology 2: 85-92. doi: 10.3109/10520298709107973

Roura SL, Montecchia C, Goldemberg A, Trucco RE, Crupkin M (1990) Biochemical and physicochemical properties of actomyosin from pre and post spawned hake (Merluccius hubbsi) stored on ice. Journal of Food Science 55: 688-692. doi: 10.1111/j.1365-2621.1990.tb05207.x
Roy BC, Ando M, Nakatani M, Okada T, Sawada Y, Itoh T, Tsukamasa Y (2012) Muscle fiber types, growth and development in the whole myotome of cultured Pacific bluefin tuna Thunnus orientalis. Fisheries Science 78: 471-483. doi: 10.1007/ s12562-011-0463-3

te Kronnie G, Tatarczuch HL, van Raamsdonk W (1983) Muscle fibre types in the myotome of stickleback, Gasterosteus aculeatus L., a histochemical, immunohistochemical an ultrastructural study. Journal of Fish Biology 22: 303-316. doi: 10.1111/j.1095-8649.1983.tb04754.x

Thorsen DH, Hale ME (2005) Development of Zebrafish (Danio rerio) Pectoral Fin Musculature. Journal of Morphology 266: 241-255. doi: 10.1002/jmor.10374

Thorsen DH, Westneat MW (2005) Diversity of pectoral fin structure and function in fishes with labriform propulsion. Journal of Morphology 263: 133-150. doi: 10.1002/jmor.10173

Vieira JP, Castello JP, Pereira LE (1998) Ictiofauna, p. 61-69. In: Seeliger U, Odebrecht C, Castello JP (Eds.) Os ecossistemas costeiro e marinho do extremo sul do Brasil. Rio Grande, Ecoscientia.

Walker JA, Wesneat MW (2002). Performance limits of labriform propulsion and correlates with fin shape and motion. Journal of Experimental Biology 205: 177-187.

Wardle C, Videler J, Altringham J (1995). Tuning in to fish swimming waves: body form, swimming mode and muscle function. Journal of Experimental Biology 198: 1629-1636.

Winterbottom R (1974) A descriptive synonymy of the striated muscles of the Teleostei. Proceedings of the Academy of Natural Sciences of Philadelphia 125: 225-317.

ZAR JH (2010) Biostatistical analysis. Upper Saddle River, Pearson Prentice Hall, $5^{\text {th }}$ ed.

Submitted: 30 May 2016

Received in revised form: 4 July 2016

Accepted: 30 July 2016

Editorial responsibility: Carolina Arruda Freire

Author Contributions: CVD and MVL designed the experiments; $\mathrm{MSH}$ conducted the experiments; MVL and MSH analyzed the data; CVD, MVL, MSH and AOD wrote the paper.

Competing Interests: The authors have declared that no competing interests exist. 